\title{
PEMIKIRAN FAZLUR RAHMAN TENTANG MODERNISASI PENDIDIKAN ISLAM
}

\author{
Siti Yumnah \\ Sekolah Tinggi Agama Islam Pancawahana Bangil \\ sitiyumnah30@gmail.com
}

\begin{abstract}
The idea put forward by Fazlur Rahman on Modernization of Islamic Education, namely: 1. Educational Objectives, Fazlur Rahman argues that the purpose of Islamic education must be oriented to the life of the world and the hereafter as well as sourced from the Qur'an. The psychological burden of Muslims in facing the West must be immediately eliminated to eliminate the psychological burden. Fazlur Rahman suggested that a comprehensive and historically comprehensive Islamic study be conducted on the development of Islamic disciplines such as theology, law, ethics, Hadith, social sciences, and philosophy, by holding on to the Qur'an as an appraiser. 2. The Education System, according to Fazlur Rahman, is to eliminate the dichotomy by integrating general science and religion 3. Students, Fazlur Rahman suggests that students must be given Qur'anic lessons, and students are given material in the disciplines of Islamic sciences 4. Educator, Fazlur Rahman offers several ideas, namely, recruiting students who have the best talent for Islam, educators must be trained at the center of Islamic studies abroad, and encourage educators to produce Islamic works creatively. 5. Educational facilities, Fazlur Rahman suggested that each library in an educational institution be equipped with Arabic and Englishlanguage books. According to Fazlur Rahman, in essence all the problems of "modernizing" Islamic education, namely making it capable of creative Islamic intellectual productivity in all fields.
\end{abstract}

Keywords: Fazlur Rahman, Modernization of Islamic education

\section{PENDAHULUAN}

Pendidikan Islam menurut Fazlur Rahman bukan sekedar perlengkapan dan peralatan fisik atau kualitas fisik pengajaran seperti buku-buku yang diajarkan ataupun struktur eksternal pendidikan, melainkan sebagai intelektualisme Islam karena baginya hal inilah yang dimaksud dengan esensi pendidikan tinggi Islam (Sutrisno, 2006: 170). Lebih lanjut ia menuturkan bahwa pendidikan Islam bisa dipahami sebagai proses menghasilkan ulama yang integratif, yang di dalam dirinya terdapat sifat-sifat kritis, kreatif, dinamis, 
inovatif, progresif, adil, jujur, dan sebagainya. Ulama yang demikian itu diharapkan dapat memberikan alternatif solusi terhadap problematika yang dihadapi oleh umat manusia sekarang ini.

Di era milenial ini, kemajuan iptek dapat mempengaruhi perkembangan sosial budaya masyarakat muslim di Indonesia pada umumnya, khususnya pendidikan Islam. Meskipun demikian, masyarakat muslim tidak bisa menghindari diri dari arus globalisasi tersebut, apalagi jika survive dan berjaya di tengah perkembangan dunia yang kian kompetitif.

Saat ini pun, pendidikan Islam telah mampu menunjukkan eksistensinya sebagai pendidikan yang fleksibel, mampu merespon perkembangan zaman, serta berorientasi ke masa depan, memiliki mutu yang unggul, egaliter, adil, demokratis, dinamis dan seterusnya. Sesuai dengan sifat dan karakternya yang demikian itu, pendidikan Islam senantiasa mengalami inovasi dari waktu ke waktu, yaitu mulai dari sistem pendidikannya (Nata, 2013: 9-10).

Berkaitan dengan itu pula pendidikan Islam memiliki corak dan karakteristik yang berbeda sejalan dengan upaya pembaharuan yang dilakukan secara terus menerus pasca generasi Nabi, sehingga dalam perjalanan selanjutnya pendidikan Islam terus mengalami perubahan, baik dari muatan atau isi (mata pelajaran), metode pendidikan, kurikulum pendidikan, maupun dari segi manajemen lembaga pendidikan Islam.

Selain itu, upaya pengembangan pendidikan Islam dilakukan karena prihatin dengan kondisi terpuruknya pendidikan Islam saat ini. Apalagi kondisi pendidikan Islam saat ini sudah termarginalkan. Kondisi tersebut tidak hanya pada bidang pendidikan semata, melainkan pada berbagai bidang seperti ekonomi, budaya dan sebagainya. Ulama yang menyuarakan semangat perbaikan kondisi umat keseluruh dunia seperti yang dilakukan salah satu tokoh pembaharu pendidikan Islam yaitu Fazlur Rahman.

Munculnya gagasan dan program modernisasi pendidikan Islam dilatarbelakangi oleh gagasan tentang "modernisasi" pemikiran dan institusi pendidikan Islam secara keseluruhan. Modernisasi Pendidikan Islam sangat erat kaitannya dengan kebangkitan gagasan program modernisasi Islam. Menurut 
Azyumardi Azra, faktor yang paling mendasar adanya istilah "modernisasi" ialah mengenai pemikiran dan institusi pendidikan Islam yang merupakan prasyarat utama bagi kebangkitan kaum muslimin di masa modern (Azyumardi Azra, 2000: 85). Karena itu, pemikiran dan institusi pendidikan Islam, haruslah dimodernisasi, lebih simpelnya harus disesuaikan dengan kerangka "modernitas", yakni mempertahankan Institusi pendidikan Islam "tradisional", akan tetapi lebih baik mengikuti perubahan ke arah yang lebih baik lagi sesuai dengan perkembangan zaman (Nata, 2013: 185).

Sementara itu, Fazlur Rahman menginginkan adanya kontribusi besar dari kaum Muslim dalam mengembangkan ilmu pengetahuan. Ia menginginkan agar umat Muslim tidak bersifat defensif (bersikap bertahan) yang berlebihan karena takut terhadap gagasan Barat tentang perkembangan pengetahuan yang akan mengancam standar moral tradisonal Islam. Ia ingin mengintegrasikan antara mata pelajaran "baru" dengan mata pelajaran "lama" supaya ramuan yang dihasilkan dari campuran ini akan sehat dan bermanfaat, yakni bersifat kondusif terhadap manfaat teknologi peradaban modern (Ngatini, 2010: 120).

\section{PEMBAHASAN}

\section{BIOGRAFI FAZLUR RAHMAN}

Fazlur Rahman dilahirkan pada tanggal 21 September tahun 1919 di Distrik Hazara, Punjab, suatu daerah di anak benua India yang sekarang terletak di sebelah barat laut Pakistan. Ia menikah dengan seorang perempuan yang bernama Ny. Bilqis Rahman (Sutrisno, 2006: 60). Ayahnya bernama Maulana Sahab al-Din, beliau merupakan seorang yang religius dan juga seorang ulama terkenal lulusan Darul Ulum Deoband. Meskipun Ayah Fazlur Rahman berpendidikan agama dengan sistem tradisional, akan tetapi beliau sangat menghargai pendidikan dengan sistem modern (Amiruddin, 2000: 9).

Semasa kecil, Fazlur Rahman sangat diperhatikan oleh ayahnya Sahab alDin dalam hal pendidikan. Ayahnya memperhatikan dalam hal mengaji dan menghafal al-Qur'an. Sehingga pada usia sepuluh tahun, Fazlur Rahman telah menghafal al-Qur'an seluruhnya. 
Tidak hanya itu, di dalam keluarganya setiap hari diterapkan ibadah seperti shalat wajib, shalat sunnah, puasa sunnah, mengeluarkan zakat, infaq, shadaqah dan ibadah lainnya, secara tepat waktu danteratur. Ia wafat pada tanggal 26 Juli 1988, di Chicago, Illinois (Sutrisno, 2000: 60-61).

Semasa hidupnya karir Fazlur Rahman terbilang cemerlang. Setelah mempelajari ilmu-ilmu dasar bersama ayahnya, kemudian melanjutkan pendidikannya ke Punjab Universitas di Lahore pada tahun 1933. Pada tahun 1940, ia menyelesaikan B. A.-nya dalam bidang Bahasa Arab pada Universitas Punjab. Kemudian dua tahun kemudian tepatnya tahun 1942, Rahman berhasil menyelesaikan Masternya dalam bidang yang sama dan Universitas yang sama pula.

Selang empat tahun, Fazlur Rahman berangkat ke Inggris untuk melanjutkan pendidikannya di Universitas Oxford dibawah bimbingan Profesor Simon Van Den Bergh dan H. A. R. Gibb, dan ia mampu menyelesaikan program Ph.D.-nya pada tahun 1949, dengan disertasi tentang Ibnu Sina. Disertasi tersebut diterbitkan oleh Oxford University Press dengan judul Avecinna's Psychology.

Ketika kuliah di Universitas Oxford, Fazlur Rahman mempunyai kesempatan untuk belajar beberapa bahasa barat seperti, Bahasa Latin, Yunani, Inggris, Jerman, Turki, Arab, dan Urdu. Dengan menguasai bahasa tersebut, ia mampu memperdalam serta memperluas keilmuannya, terutama dalam studistudi Islam melalui penelusuran literatur-literatur keislaman yang ditulis oleh para orientalis dalam bahasa-bahasa mereka (Sutrisno, 2000: 61-62).

Setelah meraih gelar Doktor of Philosophy dari Oxford University, Fazlur Rahman tidak langsung kembali ke Pakistan. Nampaknya masih ada rasa cemas akan fenomena negerinya ketika itu yang agak sulit menerima seorang sarjana keislaman yang terdidik di Barat. Untuk beberapa tahun, ia memilih untuk mengajar di Universitas Durham, Inggris, dan kemudian pindah ke Universitas McGill, Montreal, Kanada, dimana didirikan Institute of Islamic Studies oleh Wilfred Cantwell Smith, sebuah Institut pengkajian Islam yang popular di Barat sampai sekarang (Amirudin, 2000: 11-12). 
Diawal tahun 1960-an, Fazlur Rahman dipanggil kembali ke Pakistan untuk memegang sebuah lembaga penelitian yaitu Institute of Islamic Research di Kirachi. Melalui lembaga ini, ia mampu memprakarsai penerbitan Journal Islamic Studies yang hingga sekarang masih terbit secara berkala dan merupakan jurnal bertaraf Internasional. Ketika mengelola lembaga ini, Rahman telah berusaha sungguh-sungguh untuk memajukannya.

Selain menjabat menjadi Direktur Lembaga Riset Islam, Fazlur Rahman juga ditunjuk sebagai anggota Dewan Penasehat Ideologi Islam pemerintah Pakistan pada tahun 1964. Dengan kedua jabatan tersebut, ia terdorong untuk menafsirkan kembali Islam dalam istilah-istilah yang rasional dan ilmiah untuk memenuhi kebutuhan masyarakat. Akan tetapi, pada tahun 1969, Rahman melepas kedua jabatannya.

Berikut karya-karya Fazlur Rahman:

1. Kitab al-Najat dan kitab al-Syifa'(terjemah dari Ibnu Sina), London: Oxford University Press, 1952

2. Prophecy in Islam: Philosophy and Orthodoxy, London: George Allen and Unwin, 1958

3. Avicenna's Psychology, London: Oxford University Press, 1959

4. Islamic Metodology In History, Karachi: Central Institute of Islamic Research, 1965

5. Islam, London: Weidenfeld And Nicholson, 1966

6. Major Themes of The Qur'an, Minneapolis: Bibliotheca Islamica, 1980

7. Islam And Modernity: Transformation of An Intelectual Tradition, The University of Chicago Press, 1982

8. The Philosophy of Mulla Sadra, Albany: State University Of New York, 1985

9. Health and Medicine in The Islamic Tradition: Change And Identity, New York: Crossroad, 1987

\section{Modernisasi Pendidikan Islam}

Menurut Kamus Besar Bahasa Indonesia (1989:589), "modernisasi" berasal dari kata "modern" yang berarti: a) Terbaru, mutakhir, b) Sikap dan 
cara berfikir sesuai dengan perkembangan zaman. Kemudian berimbuhan "sasi", yakni "modernisasi", sehingga memiliki makna suatu proses pergeseran sikap dan mentalitas sebagai warga masyarakat untuk bisa hidup sesuai dengan perkembangan zaman.

Menurut Nurcholis Madjid bahwa modernisasi adalah proses perubahan pola berfikir dari cara kerja lama ke pola berfikir dengan cara kerja baru (Madjid, 1993: 172). Sedangkan menurut Yusran mengungkapkan bahwa modernisasi disebut juga dengan reformasi, yaitu membentuk kembali atau mengadakan perubahan terhadap suatu system yang telah ada pada suatu masa, dapat pula dimaknai sebagai perbaikan (Yusran, 1996: 1-2).

Kemudian definisi modernisasi pendidikan Islam secara umum dapat dipahami sebagai suatu ciri khas, yaitu jenis pendidikan Islam yang berlatar belakang keagamaan dan mengintegrasikan ilmu pengetahuan dan sains. Bisa juga dikatakan bahwa pendidikan yang mampu membentuk manusia yang lebih unggul dari segi intelektual maupun unggul dalam berperilaku. Dengan demikian, manifestasi dari cita-cita pendidikan Islam yaitu mencetak "Insan Kamil" yang paripurna, yaitu manusia yang sempurna dalam segala hal, sekalipun diyakini bahwa hanya Nabi Muhammadlah yang telah mencapai kesempurnaan (Syahminan, 2014:239).

Setelah diuraikan di awal mengenai definisi modernisasi, apabila dikaitkan dengan pendidikan Islam maka dapat disimpulkan bahwa modernisasi pendidikan Islam merupakan suatu ijtihad yang dilakukan oleh para ilmuwan untuk memperbaharui atau mengubah tingkah laku, cara berfikir, faham-faham, adat-istiadat, institusi-institusi lama ke yang baru dan lain sebagainya. Proses memperbaharui tersebut dilakukan untuk membimbing manusia menuju ke arah yang lebih baik sesuai dengan nilai-nilai ajaran Islam, agar bisa beradaptasi dalam perkembangan zaman.

Untuk menguji itu semua, Fazlur Rahman melalui pemikirannya baik dibidang pendidikan maupun di bidang lainnya dibangun atas dasar pemahamannya yang mendalam mengenai khazanah intelektual Islam di zaman klasik untuk ditemukan solusinya guna memecahkan berbagai masalah dalam 
kehidupan modern. Hal ini misalnya dapat dilihat dari analisis yang diberikannya terhadap pertumbuhan dan perkembangan pendidikan Islam yang dilaksanakan mulai zaman Rasulullah SAW. Sampai dengan Zaman Abbasiyah. Fazlur Rahman mengatakan bahwa pendidikan pada zaman klasik menerapkan metode membaca dan menulis, tetapi lazimnya adalah menghafal Al-Qur'an dan Hadits. Namun, pada Masa Abbasiyah, khalifah-khalifah tertentu seperti Harun Al-Rasyid dan Al-Ma'mun menekankan adu pendapat diantara para pelajar mengenai permasalahan logika, hukum, dan sebagainya (Nata, 2013: 319).

Melalui kajiannya terhadap berbagai literatur klasik, Fazlur Rahman memperkenalkan gagasan dan pemikirannya tentang pembaharuan pendidikan. Menurutnya, pembaharuan pendidikan Islam dapat dilakukan dengan cara menerima pendidikan sekuler modern, kemudian berusaha memasukkan ke dalam ajaran Islam. Upaya pembaharuan pendidikan Islam tersebut menurutnya dapat ditempuh dengan jalan, Pertama, membangkitkan ideologi umat Islam tentang pentingnya belajar dan mengembangkan ilmu pengetahuan. Seperti yang disabdakan Nabi Muhammad SAW yang artinya: "Menuntut ilmu merupakan kewajiban bagi setiap Muslim dan Muslimah". Kedua, berusaha mengikis dualisme sistem pendidikan Islam. Pada satu sisi ada pendidikan tradisional (agama), dan pada sisi lain, ada pendidikan modern (sekuler). Karena itu, perlu adanya upaya mengintegrasikan antara keduanya. Ketiga, menyadari betapa pentingnya bahasa dalam pendidikan sebagai alat untuk berkomuniakasi dalam menyampaikan pendapat-pendapat yang orisinil (Nata, 2013: 319).

Selain itu, Al-Qur'an juga menyuruh manusia untuk mempelajari kejadian yang terjadi pada diri sendiri, alam semesta lihat dalam surat (QS. Al-Sajdah: 4) dan sejarah umat manusia di muka bumi (QS. Yusuf: 111) dengan cermat dan mendalam agar mendapat pengetahuannya dengan tepat (QS. Al-Baqarah: 3133), serta agar tidak mengikuti orang yang berbuat kerusakan (QS. Ar-Rum: 41). Dengan demikian, tujuan utama pendidikan Islam yaitu untuk menyelamatkan manusia dari ketertinggalan zaman yang dimulai dari diri sendiri oleh diri sendiri dan untuk diri sendiri (Nata, 2013: 321). 


\section{Pemikiran Fazlur Rahman Tentang Modernisasi Pendidikan Islam}

\section{Definisi Modernisasi Pendidikan Islam}

Menurut Fazlur Rahman, modernisasi adalah "usaha (dari tokoh-tokoh Muslim) untuk melakukan harmonisasi antara agama dan pengaruh modernisasi dan westernisasi yang berlangsung di dunia Islam. Ia lebih menonjolkan karakteristik modernisasi pada "keharusan ijtihad", khususnya ijtihad dalam hal mu'amalah (kemasyarakatan), dan penolakan terhadap sikap jumud (kebekuan berfikir) dan taqlid (mengikuti sesuatu tanpa pemahaman) (Yusril, 1999:13).

Sedangkan pendidikan Islam seperti dikemukakan oleh Fazlur Rahman dalam bukunya (Sutrisno, 2006:170), dijelaskan bahwa bukan sekedar sarana prasarana fisik pengajaran seperti buku-buku atau struktur eksternal pendidikan, melainkan sebagai intelektualisme Islam, karena menurut Fazlur Rahman hal tersebut merupakan esensi pendidikan tinggi Islam. Dan juga merupakan pertumbuhan dan perkembangan pemikiran Islam yang orisinil, dan harus memberikan evaluasi untuk menilai seberapa jauhkah keberhasilan maupun kegagalan sebuah sistem pendidikan Islam.

\section{Dasar Pemikiran Pendidikan}

Dasar pemikiran Fazlur Rahman baik dalam bidang pendidikan maupun yang lainnya dibangun atas dasar pemahaman serta pengalamannya yang mendalam mengenai khazanah intelektual Islam di zaman klasik guna memecahkan berbagai masalah kehidupan modern. Hal ini misalnya dapat dilihat dari analisis yang diberikannya terhadap pertumbuhan dan perkembangan pendidikan Islam yang dilaksanakan mulai Rasulullah Saw sampai zaman Abbasiyah (Nata, 2013: 319).

Upaya modernisasi pendidikan Islam menurut Fazlur Rahman sebagaimana dikutip oleh Abudin Nata (2013: 320), dapat ditempuh dengan cara:

a. Membangkitkan ideologi umat Islam tentang pentingnya belajar dan mengembangkan ilmu pengetahuan. 
b. Berusaha mengikis dualisme sistem pendidikan Islam. Pada satu sisi terdapat pendidikan tradisional (agama) dan sisi lain pendidikan modern (sekuler). Karena itu perlu ada upaya mengintegrasikan antara keduanya.

c. Menyadari betapa pentingnya bahasa dalam pendidikan dan sebagai alat untuk komunikasi dalam menyampaikan pendapat-pendapat yang orisinil.

d. Pembaruan di bidang metode pendidikan Islam, yaitu beralih dari metode mengulang-ulang dan menghafal pelajaran ke metode memahami dan menganalisis.

\section{Tujuan Pendidikan menurut Fazlur Rahman}

Dengan berdasarkan pada Al-Qur'an, Fazlur Rahman mengatakan sebagaimana dikutip oleh Sutrisno (2006: 171), bahwa tujuan pendidikan adalah untuk mengembangkan manusia menjadi sedemikian rupa sehingga pengetahuan yang didapatnya akan menjadi organ pribadi yang kreatif, yang mampu memanfaatkan sumber-sumber alam untuk kebaikan dan untuk menciptakan keadilan, kejujuran, dan ketentraman dunia (Sutrisno, 2006: 171). Menurut beliau juga seperti yang dikutip oleh Muhaimin (1999: 105), tujuan pendidikan Islam selama ini lebih cenderung berorientasi pada kehidupan akhirat saja dan bersifat defensif. Tujuan pendidikan Islam harus diorientasikan kepada dunia dan akhirat sekaligus bersumber pada Al-Qur'an.

Dengan demikian, modernisasi pendidikan Islam menurut Fazlur Rahman merupakan usaha yang dilakukan oleh para tokoh-tokoh Muslim untuk melakukan harmonisasi pada agama. Yang lebih ditonjolkan ialah pada keharusan ijtihad, bukan taqlidnya. Demi tercapainya tujuan pendidikan Islam secara optimal.

\section{Sistem Pendidikan}

Masalah klasik yang tetap aktual karena masih sering dipersoalkan oleh para pakar pendidikan Islam adalah adanya dikotomi dalam sistem pendidikan Islam. Di tengah maraknya persoalan dikotomi sistem pendidikan Islam, Fazlur Rahman berupaya menawarkan solusinya seperti yang dikutip oleh Muhaimin (1999: 109-110). Menurutnya untuk menghilangkan dikotomi sistem pendidikan Islam tersebut adalah dengan cara mengintegrasikan 
antara ilmu-ilmu agama dengan ilmu-ilmu umum secara organis dan menyeluruh. Dengan demikian di dalam kurikulum maupun silabus pendidikan Islam harus tercakup baik ilmu-ilmu umum seperti ilmu-ilmu sosial, ilmu-ilmu alam dan sejarah dunia maupun ilmu-ilmu agama seperti fiqih, ilmu kalam, tafsir dan Hadits.

Pendekatan integratif seperti itu, menghasilkan adanya hubungan fungsional antara ilmu-ilmu umum dan ilmu-ilmu agama, telah berhasil melahirkan ulama-ulama yang memiliki pikiran-pikiran yang kreatif dan terpadu, serta memiliki pengetahuan luas dan mendalam. Sebagai contoh Ibnu Sina, selain ahli agama juga seorang psikologi, ia juga ahli dalam ilmu kedokteran. Demikian pula tokoh pada abad pertengahan dari Turki seperti Jalaludin Rumi, ia di samping sebagai ahli tasawuf, ia juga mahir dibidang sastra, dan musik.

\section{Peserta Didik}

Anak didik yang dihadapi oleh dunia pendidikan Islam khususnya di negara-negara Islam, yakni berkaitan dengan belum berhasilnya dikotomi antara ilmu-ilmu agama dengan ilmu-ilmu umum ditumbangkan di lembagalembaga pendidikan Islam. Belum berhasilnya dikotomi tersebut mengakibatkan rendahnya kualitas intelektual peserta didik dan munculnya pribadi-pribadi yang pecah. Kondisi tersebut pada akhirnya bisa menimbulkan moralitas ganda dari kaum Muslim. Misalnya seorang Muslim yang sholeh dan taat beribadah, di waktu yang sama bisa menjadi pemeras, koruptor, atau melakukan perbuatan tercela lainnya. Bahkan yang lebih memprihatinkan lagi dikotomi sistem pendidikan tersebut mengakibatkan tidak lahirnya peserta didik yang mempunyai komitmen spiritual dan intelektual yang mendalam terhadap Islam dari lembaga-lembaga pendidikan Islam (Muhaimin dan Mujib, 1993: 160). Dengan artian nilai-nilai ajaran Islam yang terbentuk dalam diri anak didik belum terbentuk dan teraplikasikan dalam diri anak didik tersebut. Sehingga sering terjadi hal-hal yang menyimpang pada anak didiknya.

Oleh karena itu, Menurut Fazlur Rahman sebagaimana yang dikutip 
oleh Muhaimin (1999: 111-112), ada beberapa usaha yang dapat dilakukan untuk mengatasi masalah di atas, yaitu: Pertama, peserta didik harus diberikan pelajaran Al-Qur'an melalui metode-metode yang memungkinkan, karena kitab suci Al-Qur'an yang tidak hanya sebagai sumber inspirasi, akan tetapi Al-Qur'an juga dapat sebagai rujukan paling tinggi untuk menyelesaikan masalah-masalah dalam kehidupan yang semakin kompleks. Maka dari itu, Fazlur Rahman menawarkan metode sistematisnya dalam memahami dan menafsirkan Al-Qur'an. Metode tersebut terdiri dari dua gerakan ganda atau sering disebut double movement, dimana gerakan tersebut dari situasi sekarang ke masa turunnya Al-Qur'an dan kembali lagi ke masa kini. Gerakan pertama mempunyai dua langkah yaitu:

a. Peserta didik harus memahami makna atau arti dari sebuah pernyataan dengan mengkaji situasi dan masalah historis di mana pernyataan AlQur'an tersebut merupakan jawaban. Sebelum mengkaji ayat-ayat spesifiknya, suatu kajian mengenai situasi makro dalam batasan-batasan masyarakat, agama, adat-istiadat, lembaga-lembaga dan mengenai kehidupan secara menyeluruh.

b. Mengeneralisasikan jawaban-jawaban spesifik tersebut dan menyatakannya sebagai pernyataan-pernyataan yang memiliki tujuan moral dan sosial umum yang dapat disaring dari ayat-ayat spesifik dalam latar belakang sejarah yang sering dinyatakan.

Kedua, memberikan materi disiplin ilmu-ilmu Islam secara historis, kritis dan holistik. Disiplin ilmu-ilmu Islam tersebut meliputi: teologi, hukum etika, ilmu-ilmu sosial dan filsafat.

\section{Pendidik}

Pendidik adalah orang dewasa yang bertanggung jawab memberikan bimbingan atau memberi bantuan kepada anak didik dalam perkembangan jasmani maupun rohaninya agar mencapai kedewasaannya, mampu melaksanakan tugasnya sebagai makhluk Allah, khalifah di muka bumi, sebagai makhluk sosial, dan sebagai individu yang mampu berdirikari. Istilah lain dari pendidik ialah guru. Kedua istilah itu hampir sama istilahnya, 
bedanya kalau istilah guru seringkali dipakai dilingkungan pendidikan formal, sedangkan pendidikan seringkali dipakai dilingkungan formal, nonformal, dan informal (Nur dan Abu, 1997: 71).

Secara umum pendidik yang pertama dan utama adalah orang tua sendiri yang bertanggungjawab penuh atas perkembangan kemajuan anak kandungnya, sebab kesuksesan seorang anak ialah bergantung pada kesuksesan orang tua dalam mendidik anaknya. Seperti firman Allah (QS. AtTahrim 66: 6): "Peliharalah dirimu dan keluargamu dari api neraka...". Namun karena tuntutan sehingga anaknya diserahkan kepada lembaga pendidikan. Penyerahan anak kepada lembaga pendidikan bukan lantas orangtua lepas tanggungjawabnya sebagai pendidik yang pertama dan utama, akan tetapi orangtua tetap masih mempunyai kewajiban untuk mendidik anak tersebut.

Dengan demikian menurut fazlur Rahman, untuk mendapatkan pendidikan yang berkualitas dan professional di lembaga-lembaga pendidikan Islam sangat sulit untuk didapatkan. Namun upaya untuk mengatasi hal tersebut Fazlur Rahman memberikan beberapa gagasannya:

a. Merekrut dan mempersiapkan peserta didik yang memiliki bakat-bakat terbaik dan mempunyai komitmen yang tinggi terhadap agama Islam.

b. Mengangkat lulusan madrasah yang relatif cerdas atau merujuk kepada sarjana-sarjana modern yang telah memperoleh gelar keilmuannya tinggi sebagai guru besar pada bidang bahasa Arab dan sejarah Islam.

c. Pendidik harus dilatih di pusat-pusat studi keislaman di luar negeri.

d. Mengangkat beberapa lulusan madrasah yang memiliki pengetahuan bahasa Inggris dan mencoba melatih mereka dalam teknik riset modern da sebaliknya menarik para lulusan universitas bidang filsafat dan ilmuilmu sosial dan member mereka pelajaran bahasa Arab dan disiplin-disiplin Islam klasik seperti Hadits, dan yuriprudensi Islam.

e. Menggiatkan para pendidik untuk melahirkan karya-karya keislaman secara kreatif dan memiliki tujuan. Di samping menulis karya-karya tentang sejarah, filsafat, seni, juga harus mengkonsentrasikannya kembali 
kepada pemikiran Islam. Dan para pendidik juga harus bersungguhsungguh dalam mengadakan penelitian dan berusaha untuk menerbitkan karyanya tersebut. Bagi mereka yang memiliki karya yang bagus, harus diberikan penghargaan seperti meningkatkan gajinya.

\section{Sarana Pendidikan}

Sarana yang berupa gedung dan perpustakaan amat berhubungan dengan mutu sekolah. Tokoh-tokoh pendidikan Islam terdahulu sudah mengetahui betapa pentingnya sarana untuk menunjang mutu pendidikan, dimulai dari yang sederhana. Seperti pengajaran di rumah dan masjid. Dahulu rumah Rasulullah pernah dijadikan sebagai tempat belajar. Sedangkan rumah Arqam ibn Arqam pernah dijadikan oleh para sahabat untuk mempelajari pokok-pokok ajaran Islam dan pengajaran hafalan AlQur'an.

Sarana pendidikan seperti perpustakaan pada masa pertengahan memberikan saham yang besar bagi peningkatan kualitas lembaga pendidikan dan intelektual umat Islam. Dalam sejarah Islam perpustakaan dapat dikategorikan ke dalam tiga jenis, yaitu:

a. Perpustakaan umum yang biasanya merupakan bagian dari masjid, madrasah, atau lembaga-lembaga pendidikan lainnya. Perpustakaan ini terbuka untuk siapa saja yang ingin menggunakannya. Yang tergolong di dalam perpustakaan ini antara lain Bait al-Hikmah, Dar al-Hikmah, dan Dar al-'I/mi.

b. Perpustakaan semi-umum yang hanya terbuka untuk kalangan tertentu saja, biasanya hanya untuk para ilmuwan dan bangsawan saja, dan letaknya sering kali di lingkungan Istana.

c. Perpustakaan pribadi merupakan perpustakaan milik individu, baik seorang sarjana maupun orang yang hobi mengumpulkan buku untuk sekedar kesenangan saja.

Dari bebagai pengalaman Fazlur Rahman selama mengunjungi berbagai negara Islam yang disinggahinya menunjukkan bahwa keadaan perpustakaan di lembaga-lembaga pendidikan Islam tersebut masih belum 
memadai, terutama pada jumlah buku-bukunya. Terutama buku-buku yang berbahasa Arab dan berbahasa Inggris. Untuk mengatasi masalah tersebut, Fazlur Rahman mengusulkan agar fasilitas perpustakaan harus dilengkapi dengan buku-buku berbahasa Arab dan berbahasa Inggris (Muhaimin, 1999: 117-118).

\section{Relevansi Pemikiran Fazlur Rahman tentang Modernisasi Pendidikan Islam dengan Pendidikan Islam masa kini}

Dari pemaparan mengenai gagasan modernisasi pendidikan Islam yang dikemukakan oleh Fazlur Rahman di atas, maka ditemukan beberapa relevansi dari pemikiran Fazlur Rahman tentang modernisasi pendidikan Islam dengan modernisasi pendidikan Islam masa kini yaitu:

\section{Pemikiran modernisasi pendidikan Islam}

Secara singkat pemikiran modernisasi pendidikan Islam menurut Fazlur Rahman ialah suatu usaha untuk melakukan harmonisasi antara agama dari pengaruh modernisasi dan westernisasi yang berlangsung di dunia Islam. Yang lebih ditonjolkan ialah pada "keharusan ijtihad", khususnya ijtihad dalam hal mu'amalah (kemasyarakatan), dan penolakan terhadap sikap jumud (kebekuan berfikir) dan taqlid (mengikuti sesuatu tanpa pemahaman).

Hal tersebut sangat relevan dengan pemikiran modernisasi pendidikan Islam masa kini yaitu, suatu usaha yang dilakukan untuk memperbarui atau mengubah tingkah laku, cara berfikir, faham-faham, adat-istiadat, institusiinstitusi lama dan lain sebagainya. Proses memperbarui tersebut dilakukan guna membimbing manusia menuju lebih baik yang sesuai dengan ajaran Islam, agar bisa hidup dalam perkembangan zaman.

Pada intinya semua umat muslim diharuskan untuk bisa mengubah pola berfikir yang lama yang bersifat tradisional, ke arah cara berfikir yang baru yang bersifat modern guna untuk mengembangkan pemikiran islam sesuai dengan perkembangan zaman dan ilmu pengetahuan. Khususnya terhadap perkembangan pendidikan Islam. 


\section{Tujuan Pendidikan}

Selanjutnya mengenai tujuan pendidikan Islam, Fazlur Rahman memaparkan bahwa tujuan pendidikan harus didasarkan pada nilai-nilai AlQur'an, lebih lanjut ia mengatakan, tujuan pendidikan adalah untuk mengembangkan manusia menjadi sedemikian rupa sehingga pengetahuan yang didapatnya akan menjadi pribadi yang kreatif, yang mampu memanfaatkan sumber-sumber alam untuk kemaslahatan umat Islam dan untuk menciptakan keadilan, kejujuran, dan ketentraman dunia.

Ungkapan tersebut sevisi dengan tujuan pendidikan masa kini yaitu, mencapai pertumbuhan yang seimbang dalam kepribadian manusia secara total melalui pelatihan spiritual, kecerdasan, rasio, perasaan dan panca indera. Oleh karena itu pendidikan seharusnya memberikan pelayanan bagi pertumbuhan manusia dalam segala aspeknya yang meliputi aspek spiritual, intelektual, imajinasi, fisik, ilmiah, linguistik. Baik secara individu maupaun secara kolektif, di samping memotivasi semua aspek tersebut ke arah kebaikan dan pencapaian kesempurnaan.

Dengan demikian tujuan pendidikan tidak hanya berorientasi ke akhirat saja, akan tetapi orientasinya harus seimbang antara dunia dan akhirat. Karena manusia di dunia ini memiliki tugas sebagai khalifah di muka bumi, yakni sebagai pengelola alam demi mencapai kemaslahatan semua umat manusia. Dan pada akhirnya tujuan pendidikan bertumpu pada terealisasinya ketundukan kepada Allah SWT secara total baik dalam level individu, komunitas dan manusia secara luas.

\section{Sistem Pendidikan}

Menurut Fazlur Rahman sistem pendidikan Islam sekarang ini sedang terjangkiti penyakit dikotomi, maka dari itu untuk menghilangkan dikotomi dalam sistem pendidikan Islam, ia memberikan sebuah solusi alternatif dengan cara mengintegrasikan antara ilmu-ilmu agama dengan ilmu-ilmu umum secara organis dan menyeluruh. Dengan demikian di dalam kurikulum maupun silabus pendidikan Islam harus tercakup baik ilmu-ilmu umum seperti ilmu-ilmu sosial, ilmu-ilmu alam dan sejarah dunia maupun ilmu-ilmu 
agama seperti fiqh, ilmu kalam, tafsir dan Hadits.

Sedangkan sistem pendidikan masa kini di Indonesia adalah mengacu pada Sistem Pendidikan Nasional yang merupakan sistem pendidikan yang akan membawa kemajuan dan perkembangan bangsa dan menjawab tantangan zaman yang selalu berubah hal ini sebagaimana visi dan misi Sistem Pendidikan Nasional yang tertuang dalam UU RI NO. 20 tahun 2003 tentang SISDIKNAS adalah sebagai berikut: "Terwujudnya sistem pendidikan sebagai pranata sosial yang kuat dan berwibawa untuk memberdayakan semua warga Negara Indonesia berkembang menjadi manusia yang berkualitas sehingga mampu dan proaktif menjawab tantangan zaman yang selalu berubah".

Di dalam kurikulum diharapkan dapat memenuhi sifat-sifat integrality, holistic, wholistic, continuity dan consistency serta dapat memenuhi kebutuhan peserta didik, pasar, dan pengembangan IPTEK. Karakteristik itu dapat diketahui karena terjadi kemanunggalan yang fungsional dalam bidang studi bukan secara dikotomi, dimana ada pemisahan antara ilmu pengetahuan dan agama misalnya. Karena itu seyogyanya materi ajar untuk ilmu-ilmu umum bersumber dari nilai-nilai agama, dan berkembang melalui metodologi pembelajaran yang tepat.

\section{Peserta Didik}

Tujuan dikembangkan peserta didik yang memiliki daya kritis dan kreatif dalam pendidikan Islam, menurut Fazlur Rahman seperti yang dikutip oleh Sutrisno (2006: 185), ialah mampu mengembangkan anak didik yang mempunyai sifat yang kritis dan kreatif. Anak didik yang memiliki sifat tersebut paling tidak mempunyai tiga ciri-ciri, yaitu:

a. Mempunyai pemikiran yang orisinil atau asli

b. Mempunyai keluwesan

c. Menunjukkan kelancaran proses berfikir.

Dengan ciri-ciri tersebut peserta didik mampu menghasilkan sesuatu yang berbeda dengan yang lain, terutama pada kematangan dan kedewasaan berpikir kritis. 
Hal tersebut juga relevan dengan ciri-ciri peserta didik di era kontemporer sekarang ini, yakni tentang potensi yang dimiliki oleh peserta didik. Potensi atau fitrah yang dimiliki manusia, pada hakikatnya merupakan kemampuan dasar manusia yang meliputi kemampuan mempertahankan kelestarian kehidupannya, kemampuan rasional, maupun kemampuan spiritual. Untuk itu diperlukan berbagai upaya dalam mengembangkan dan memperkaya potensi tersebut secara aktif.

\section{Pendidik}

Seorang pendidik seharusnya memiliki kualitas, kreatifitas, pemikiran yang terpadu serta profesional. Menurut Fazlur Rahman, ada beberapa usaha yang dilakukan diantaranya yaitu menggiatkan pendidik untuk melakukan penelitian dan menghasilkan karya-karya ilmiah. Dalam artian, mampu menafsirkan hal-hal yang lama dalam bahasa yang baru sesuai dengan perkembangan zaman.

Relevansinya, pendidik di era globalisasi saat ini memiliki tantangan yang cukup berat, peserta didik berkembang menjadi semakin cerdas dan kritis, seringkali menuntut perlakuan demokratis, adil, bijaksana, manusiawi, egaliter, cepat, tepat, dan memuaskan. Semula praktik pendidikan berpusat pada pendidik berpindah menjadi kepada berpusat peserta didik dengan menerapkan model pembelajaran yang sesuai dengan kondisi tersebut. Untuk mengatasinya, pendidik dituntut untuk meningkatkan kemampuan profesionalnya dengan melakukan up dating kompetensi.

Adapun modernisasi pendidikan Islam menurut Fazlur Rahman yang tidak relevan dengan modernisasi pendidikan Islam masa kini ialah mengenai sarana pendidikan. yang mana saat ini sarana pendidikan sudah mengalami perkembangan dan perubahan. Buku-buku yang berbahasa Arab dan inggris pun sudah mulai dikumpulkan atau ditemukan di perpustakaan, baik di perguruan tinggi maupun di sekolah menengah. 


\section{PENUTUP}

Upaya modernisasi pendidikan Islam Fazlur Rahman dilatarbelakangi oleh pengalaman dan karir pendidikannya selama menempuh pendidikan di negara Barat. Dan juga dia melihat adanya kemunduran dari umat Islam yakni masalah pendidikan. Kemudian dia banyak mengadopsi pemikiran modernis dari Barat mengenai konsep pendidikan yang ada di Barat. Namun Fazlur Rahman mempunyai gagasan untuk memperbarui sistem pendidikan Islam dengan cara mengintegrasikan ilmu pengetahuan umum dan ilmu pengetahuan Islam. Agar cara berpikir umat Islam tidak mengalami kejumudan demi kebangkitan dunia Islam. 


\section{DAFTAR PUSTAKA}

Amirudin, Hasbi. 2000. Konsep Negara Islam Menurut Fazlur Rahman, Yogyakarta: UII Press.

Azra, Azyumardi. 2000. Pendidikan Islam Tradisi dan Modernisasi Menuju Milineum Baru. Jakarta: Logos Wacana Ilmu.

Mahendra, Yusril Ihza. 1999. Modernisme dan Fundamentalisme dalam Politik Islam. Jakarta: Paramadina.

Madjid, Nurcholis. 1993. Islam, Kemodernan, dan Keindonesiaan. Bandung: Mizan.

Muhaimin. 1999. Kontroversi Pemikiran Fazlur Rahman: Studi Kritis Pembaharuan Pendidikan Islam. Cirebon: Pustaka Dinamika.

Mujib, Abdul \& Muhaimin. 1993. Pemikiran Pendidikan Islam: Kajian Filosofi dan Kerangka Dasar Operasionalnya. Bandung: Trigenda Karya.

Nata, Abuddin. 2013. Kapita Selekta Pendidikan Islam. Jakarta: PT. Raja Grafindo Persada.

S. Lestari, Ngatini. 2010. Pengantar Abdul Rachmad, Pendidikan Islam Kontekstual. Yogyakarta: PT. Pustaka Pelajar'.

Sutrisno. 2006. Fazlur Rahman (Kajian terhadap metode, epistemology, dan system pendidikan). Yogyakarta: Pustaka Pelajar.

Tabrani, Yusran. 1996. Prilaku Organisasi. Bandung: Sinar Baru. 